\title{
A descentralização do sujeito lírico em Micheliny Verunschk
}

DOI: http://dx.doi.org/10.21165/el.v48i2.2241

\section{Édila de Cássia Souza Santana'}

\section{Resumo}

O presente artigo propõe-se a analisar o poema "Infibulação", presente em Geografia intima do deserto (2003), da escritora pernambucana Micheliny Verunschk. A partir da análise do poema, discutimos como se configura a intimidade na poesia de Micheliny, que se manifesta de maneira contrária à configuração presente na tradição, ao voltar-se para o exterior, projetando o sujeito lírico para fora de si (COLLOT, 2013). Nesse sentido, se estabelece a discussão do sujeito lírico descentrado que percorre outros espaços, outros objetos e propõe uma nova forma de estetização que problematiza as noções de subjetividade e de lirismo, mediante um novo olhar à luz de novas teorias. Uma poesia que opta pela exploração da linguagem, do mundo e das coisas e não do sujeito em si.

Palavras-chave: poesia contemporânea; Micheliny Verunschk; subjetividade.

1 Universidade Federal de Mato Grosso do Sul (UFMS), Três Lagoas, Mato Grosso do Sul, Brasil; kassiaedila@yahoo.com.br; https://orcid.org/0000-0002-2683-7584 


\title{
The decentralization of the lyrical subject in Micheliny Verunschk
}

\begin{abstract}
The present article proposes to analyze the poem "Infibulation", present in Geografia intima do deserto (2003), from the pernambucana writer Micheliny Verunschk. From the analysis of the poem, we discussed how intimacy is configured in the poetry of Micheliny, which manifests itself in a contrary way to the present configuration in the tradition, when returns to the outside, projecting the lyrical subject out of itself (COLLOT, 2013). In this way, the discussion of the not centralized lyrical subject that crosses other spaces, other objects is established and proposes a new form of aestheticization that problematizes the notions of subjectivity and lyricism, through a new look in the light of new theories. A poetry that opts for the exploration of language, the world and things and not the subject itself.
\end{abstract}

Keywords: contemporary poetry; Micheliny Verunschk; subjectivity.

\section{Introdução}

Micheliny Verunschk é uma jovem poeta pernambucana nascida em Recife em 1972, atualmente radicada em São Paulo. Publicou os livros Geografia íntima do deserto (2003) e Cartografia da noite (2011), que tiveram boa repercussão nacional. Ainda em 2003 publicou O observador e o nada, pelas Edições Bagaço. Foi finalista do Prêmio Portugal Telecom em 2004 com Geografia intima do Deserto, que foi prefaciado pelo crítico João Alexandre Barbosa, que a considera como uma "voz singular" no contexto atual e uma aposta no cenário literário brasileiro. É também autora dos romances 0 peso do coração de um homem (2017), Aqui, no coração do inferno (2016) e Nossa Teresa - vida e morte de uma santa suicida (2014). O último foi ganhador do prêmio São Paulo de Literatura 2015 - categoria melhor romance de 2015 - autor estreante acima de 40 anos e foi finalista do Prêmio Rio de Literatura 2015.

Sua poesia é reconhecida como um projeto filiado à poética do seu conterrâneo João Cabral de Melo Neto, pelo modo de articulação poética, no qual podemos observar uma voz lírica que extrapola o lirismo para fora do espaço da subjetividade. Uma voz que percorre outros espaços, buscando na exterioridade, nas coisas, outra maneira de captar a emoção lírica.

Das muitas vozes constituintes do cenário atual da literatura brasileira, a poética de Micheliny Verunschk configura-se por meio de um lirismo que não consiste em expressar movimentos interiores e sim a emoção que nasce do contato com as coisas exteriores. O sujeito lírico "se constitui no ponto de encontro do interior e do exterior, do mundo e da linguagem" (COLLOT, 2013, p. 230). A subjetividade concentrada no próprio sujeito dá espaço a um sujeito lírico que se desprende de si e vai de encontro ao outro. Nesse 
movimento, o sujeito se afasta de si para se descobrir no outro. "Seu canto mais particular, ele tem chances de produzi-lo no momento em que se ocupa muito menos dele mesmo do que de outra coisa, em que ele se ocupa muito mais do mundo do que dele mesmo" (COLLOT, 2013, p. 236). A percepção lírica é extraída do mundo: objetos e coisas. A voz lírica não advém de movimentos interiores concentrados a se expressar, mas de exteriores. O sujeito sai de si e dá a palavra às coisas.

Para melhor compreendermos a tradição poética que Verunschk filia, e assim analisarmos a descentralização do sujeito lírico no poema "Infibulação", faremos um breve percurso teórico de alguns conceitos da lírica, que permitem entender de onde parte a descentralização, tendo em vista o lugar antes ocupado pelo eu lírico, o centro. Contrária à percepção lírica da poesia de Verunschk pela configuração de uma poética das coisas e não do sujeito em si é a percepção defendida por Hegel (1997), pela sistematização e divulgação de um conceito de poesia lírica entendida como subjetividade, por oposição à poesia épica, que seria o gênero da objetividade. Hegel assevera que o sujeito é o foco da enunciação lírica e não o objeto, acreditando que o poeta, ao trazer a representação do objeto, o sujeito que representa e sente em sua atividade poética desaparece diante da objetividade daquilo que ele coloca para fora a partir de si (HEGEL, 1997).

O caráter universal da lírica proposta por Hegel está na necessidade do sujeito de se expressar e de perceber o ânimo na exteriorização de si mesmo. O verdadeiro poeta lírico vive em si mesmo. Portanto, seu tema principal é o livre movimento dos seus próprios sentimentos e meditações. Por consequência, ele deve "procurar em si mesmo o estímulo e o conteúdo" (HEGEL, 1997, p. 519), tornando para "si mesmo uma obra de arte", é "o príncipe e motivo da sua inspiração" (HEGEL, 1997, p. 519). Dessa forma não há necessidade de tomar como ponto de partida realidades exteriores. Se isso acontecer,

\begin{abstract}
Não é a objetividade real e a sua pintura plástica que constituem o elemento verdadeiramente lírico, mas o eco que esta realidade objetiva provoca na alma ou o sentimento que desperta, de modo que não contemplamos tal realidade ou tal objeto, mas o sentimento que reflete e em nós provoca um sentimento análogo. (HEGEL, 1997, p. 533).
\end{abstract}

Em suma, para Hegel, o poeta lírico constitui um mundo subjetivo, fechado em si mesmo. As circunstâncias exteriores, a realidade objetiva não lhe são senão um pretexto para exprimir a si mesmo, com seu estado de alma. De qualquer maneira, o movimento é sempre o interno. Hegel considera uma exceção a existência na poesia ditirâmbica e nos salmos do Antigo Testamento de um poeta que expressa a realidade objetiva sem pretexto de falar de si. Portanto ele "sai de si mesmo". Essa saída de si dá-se por meio da transcendência. O sujeito apenas sai de si quando entra em contato com algum ser, considerado por ele superior. Isso pode acontecer tanto pela exaltação religiosa, como 
também por algum estado de euforia do sujeito, no caso da poesia ditirâmbica. Ao contrário, o sujeito sempre falava de si mesmo.

De acordo com Collot, a exceção proposta por Hegel, na poesia moderna, é uma regra o sujeito lírico fora de si. Porém, a saída do sujeito para fora de si no contexto moderno não ocorre por transcendência, em vista de uma configuração social que não cede a encantos e de um sujeito desacreditado de crenças e religiões.

\begin{abstract}
Aos olhos de uma consciência moderna que não pode mais cantar Deus ou o Ser ideal por meio das palavras e das maravilhas da criação ou da criatura, o sujeito que se lança para fora de si vê-se atirado em um mundo e em uma linguagem desencantados. A transcendência não era senão a máscara de uma contingência, uma ilusão lírica. Ceder ao canto e ao êxtase não é se deixar enganar pela língua, ser ludibriado pelo mundo e pelos outros? Nada de tão brilhante. Não há por que sair por aí proclamando sua submissão. (COLLOT, 2013, p. 222-223).
\end{abstract}

Deacordo com Dominique Combe(2009-2010), a crítica de Hegel faz parte de uma herança filosófica e crítica difundida pelo romantismo pela releitura feita da tripartição retórica pseudoaristotélica nos gêneros épico, dramático e lírico, à luz da distinção gramatical entre as pessoas. É dessa forma que, para Hegel, a poesia lírica é essencialmente subjetiva, em função do papel preeminente que ela confere ao eu.

Por outro lado, Emil Staiger (1969, p. 58) afırma que se a lírica não é o gênero da objetividade, também não é o da subjetividade: "Se ela não representa o mundo exterior também não representa, contudo, o interior. O que se dá é que 'interno' e 'externo' não estão absolutamente diversificados em poesia lírica". Staiger (1969) acredita na fusão da subjetividade com a objetividade na constituição da lírica. Nesse sentido, a atitude fundamental da lírica é o não distanciamento entre o eu e o mundo. Quanto menor o distanciamento, maior a fusão e mais a composição se aproxima de uma suposta lírica pura.

Os sentimentos, os semi-sentimentos, todos os estados mais secretos e mais profundos de nossa interioridade não são eles entrelaçados da maneira mais estranha a uma paisagem, uma estação, uma condição da atmosfera, um sopro de vento? [...]. Se queremos nos encontrar, não podemos mergulhar em nós mesmos: é do lado de fora que nós nos encontraremos, exteriormente. (STAIGER, 1969, p. 52). 
A experiência poética é a da alteridade, da outridade, pois "[...] se queremos encontrar a nós mesmos, não podemos descer ao nosso íntimo; temos que ser buscados fora, sim, fora de nós" (STAIGER, 1969, p. 60). Não há sujeito sem a existência do objeto. A falta de contato com o objeto exclui a possibilidade de encontro do homem consigo mesmo pela sua interdependência do outro. A objetividade, por esse ponto de vista, também é uma forma de garantir a subjetividade, o que faz dessa interação um ponto importante na visão de Staiger.

Hegel nega a objetividade em favor da subjetividade. Por seu turno, Staiger acredita na fusão de ambas para a composição de uma lírica pura. Em contrapartida, algumas teorias difundidas na modernidade integram a ideia do desaparecimento do sujeito lírico, o desaparecimento da subjetividade. Ortega y Gasset (2005), ao analisar o percurso da arte desde o período romântico até as vanguardas do século, perceberam o que as artes tinham em comum: "desumanização", isto é, o afastamento da arte da vida cotidiana compartilhada pelos homens. A despersonalização, entendida como a separação entre o homem e a obra, seria um dos procedimentos dessa desumanização. Nesse sentido, o homem que poetiza desaparece. O artista não participa como pessoa, mas como consciência que poetiza, como operador da língua (FRIEDRICH, 1991, p. 17).

Para Collot (2013, p. 227), é o "[...] desaparecimento elocutório do poeta". Ele se afasta da referência à sua pessoa e à sua biografia, não excluindo a expressão de sua experiência e de sua afetividade. "Mas esta não se opera paradoxalmente senão pela evocação de uma coisa e da criação de um objeto verbal" (COLLOT, 2013, p. 227). Nesse sentido, o que sustenta a voz que fala no poema é a própria linguagem em si. O eu que fala configura-se como um ser de linguagem, o sujeito da enunciação ou um eu lírico. A atenção é voltada para o texto, para a linguagem e não exclusivamente para o homem. Porém, isso não exclui a consciência que poetiza, a expressão da experiência do poeta e principalmente a escolha do objeto e a seleção da linguagem. Por isso o que desaparece é o elocutório do poeta.

Hambuger (2008, p. 73) nomeia de identidades perdidas provocadas pelo "mergulho no abismo. [...] "O 'eu' sobre a poesia que se escreve se torna apenas uma multiplicidade, de alternativas, possibilidade e potencialidades" (HAMBUGER, 2008, p. 73). Nesse sentido, "O eu de um poeta era o que esse poeta escolhia fazer dele, sua identidade devendo ser encontrada apenas nos corpos que ele escolhia ocupar" (HAMBUGER, 2008, p. 74). O eu se dispersa e pode ser encontrado em outros corpos, em outros objetos. Assim, o eu que fala na poesia não é necessariamente o eu do poeta.

Como dito anteriormente, há muitas vozes que formam a poesia moderna. A ideia da despersonalização é mais uma a formar as tendências da poesia. A poesia moderna, como notou Alfonso Berardinelli (2007), é composta por várias e dissonantes vozes. Bosi (1996), por seu lado, acredita que o momento moderno é o mais complexo em termos de diversidades. 


\begin{abstract}
Quisesse alguém mapear as correntes cruzadas ou paralelas da crítica recente, deveria fazer o trabalho de um cartógrafo de meandros. As águas, mal divididas, fluem umas nas outras. 0 que parecia por um momento unido, está prestes a apartar-se. O que, tempos atrás, corria em leito próprio agora se espalha alagando as margens e impedindo que o desenhista separe com traço nítido os cursos principais e os seus afluentes. (BOSI, 1996, p. 38).
\end{abstract}

Umas das discussões nesse sentido vai de encontro ao lugar que o sujeito lírico pode ocupar, pensando na sua saída do centro e no seu suposto desaparecimento. O sair de si e ir de encontro ao mundo respalda a consciência que esse sujeito não desapareceu, e sim ocupou outros lugares. Collot (2013), contrariando as noções de Hegel e dos que acreditam no desaparecimento do sujeito lírico, defende que há uma redefinição do sujeito lírico pela recusa do lirismo entendido como expressão do eu. Collot (2013, p. 222) defende a ideia do sujeito "fora de si", do "ser projetado para o exterior" que vai "ao encontro do mundo e do outro" como forma de construção da emoção lírica.

Essa performance não implica uma transcendência, como propôs Hegel aos salmos do Antigo Testamento, mas um voltar-se para a realidade exterior, para as coisas. O sujeito lírico cessa de se pertencer e dá a experiência desse pertencimento ao outro, ao tempo, ao mundo e à linguagem. Uma alteridade sem significar transcendência, um ser que deixa de se pertencer para pertencer ao outro sem desaparecer.

Ora, esse privilégio concedido ao objeto de sensação e de linguagem não implica, para eles, o desaparecimento puro e simples do sujeito em favor de uma objetividade improvável, mas, antes, sua transformação. Através dos objetos que ele convoca e constrói, o sujeito não exprime mais um foro interior e anterior: ele se inventa do lado de fora e no futuro, no movimento de uma emoção que o faz sair de si para se encontrar e para reunir-se aos outros, no horizonte do poema. (COLLOT, 2013, p. 229).

A transformação do sujeito ou o seu descentramento dispensa o lirismo como expressão do eu, ao negar o movimento interior em função de um movimento que valorize a materialidade das palavras e das coisas e o coloca para fora de si para ir de encontro com o outro. Uma poesia que opta pela exploração da linguagem, do mundo e das coisas e não do sujeito em si. É a essa via de produção que a poética de Micheliny Verunschk se filia. A poeta converte em matéria de poesia os movimentos exteriores manifestos na materialidade das coisas e dos objetos, de forma que a intimidade manifesta é a dos objetos e não do sujeito. Uma poesia que nega a expressão do eu em favor da concretude das coisas. 
Geografia intima do deserto (2003) ilustra essa performance da poeta ao transformar em matéria de poesia movimentos exteriores. Tudo pode ser convertido em objeto de poesia, a exemplo do poema "Infibulação", em que se percebe a transformação de um ritual sagrado para muitos e para outros um ato desumano e cruel, em poesia.

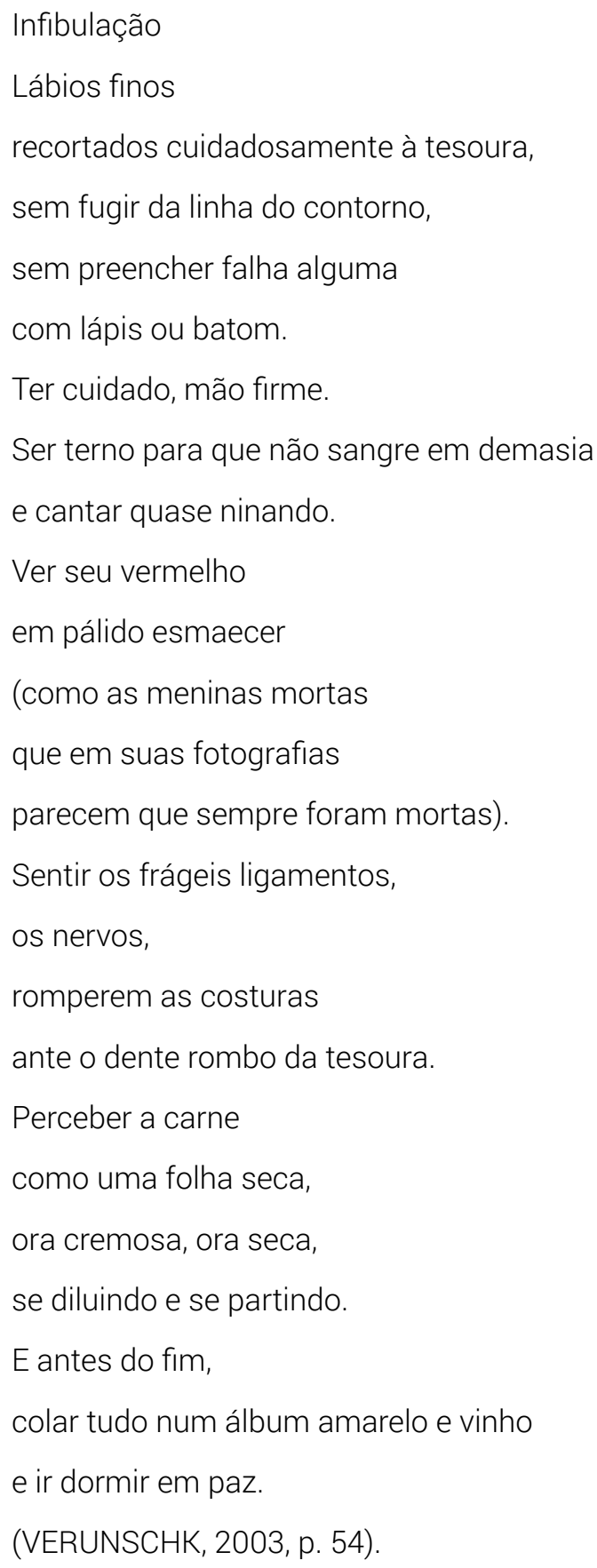


O título do poema, a escolha vocabular e a descrição minuciosa de uma cena captada pelo eu lírico permitem que o poema descreva, de forma gradativa, um procedimento que faz parte de uma prática realizada em alguns países da África e da Ásia, que consiste na mutilação do órgão genital feminino, conhecida também por circuncisão feminina, pela remoção ritualista de parte ou de todos os órgãos sexuais externos femininos. A infibulação é considerada o procedimento mais grave da mutilação, que é a remoção dos pequenos lábios, o encerramento da vulva, costurando os grandes lábios para que não sintam prazer sexual. A incisão é feita nas meninas, no início da puberdade, pelas mulheres mais velhas. No poema, a poeta, a seu modo, reinventa tal prática de forma sensível e delicada, contrastando com a dureza e a crueldade do ato.

No primeiro verso, temos a apresentação do objeto mutilado, os "Lábios finos", representando os pequenos lábios que são removidos do órgão genital feminino. A expressão utilizada pode denotar também a delicadeza do órgão em contraste com o ato ao qual é submetido. O segundo, o terceiro e o quarto versos: "recortados cuidadosamente à tesoura, /sem fugir da linha do contorno, /sem preencher falha alguma/com lápis ou batom" (VERUNSCHK, 2003, p. 54), descrevem o quadro de procedimentos da infibulação, a remoção dos lábios. Diferente do que acontece entre as africanas, onde a prática ocorre, a poeta descreve com suavidade e delicadeza o ato, como se quisesse demonstrar a forma como tal procedimento deveria ser feito: remover cuidadosamente à tesoura, seguindo roteiros e técnicas para não incorrer em erros. Também sugere a fragilidade de um objeto que merece ser tratado cuidadosamente.

"Cuidadosamente a tesoura" (VERUNSCHK, 2003, p. 54) suaviza a situação e retira o aspecto brusco e bruto dos outros instrumentos que são utilizados na remoção. Em muitos casos, a remoção é feita com faca ou mesmo com caco de vidro, sem esterilização ou anestesia. Os versos 5, 6 e 7: "Ter cuidado, mão firme./Ser terno para que não sangre em demasia/e cantar quase ninando" (VERUNSCHK, 2003, p. 54) dão continuidade à forma minuciosa com que é descrita a infibulação. Continuam com a ideia dos versos anteriores, no cuidado com que deve ser realizado tal procedimento. No sexto verso, a poeta chama atenção para a forma afetuosa que o circuncisador deve realizar a operação, que exprime a delicadeza que o ato exige para que a menina não sofra tanto, como também não sangrar muito.

Considerando que na metade dos países onde o ritual acontece, com dados disponíveis, a maior parte das jovens é mutilada antes dos cinco anos de idade, o poema tenta mostrar o porquê de exigir ternura, que está não apenas na realização do ato, mas sobretudo no sujeito que passará por ele. Aqui entendemos que a delicadeza com que a voz poética descreve que a infibulação decorre também da fragilidade do sujeito que passa pelo procedimento. Por isso, como forma de amenizar a dor, exige que se cante para que essa criança consiga dormir e assim não sofrer tanto. A insinuação vai mais longe: quem faz a infibulação são as mulheres mais velhas, as mães e as avós. Considerando que a 
própria mãe faz a incisão, como demonstração de ternura, é importante que ela cante, uma vez que as cantigas de ninar remetem à ideia do acalento que é feito com os bebês para dormirem ao se sentirem incomodados com algo. O poema sugere essa ideia, como forma de acalmar a menina submetida à infibulação, como se isso fosse possível, considerando a complexidade e a gravidade do momento, o que denota uma certa ironia do eu lírico, que demonstra a sutilidade e ironia da própria poeta, na sua voz feminina.

Nos versos 8, 9, 10, 11 e 12, o eu lírico continua concentrado nas ações do sujeito que faz o ritual e através do olhar dele localiza a menina que, em decorrência da perda de sangue em demasia, já alertada antes pelo eu lírico, perde a cor, a luminosidade que significa vida: "Ver seu vermelho/em pálido esmaecer" (VERUNSCHK, 2003, p. 54). Podemos inferir a partir desses versos tanto a ideia de perder o sangue no ato da circuncisão e ficar pálida até chegar à morte física, como também a perda da vida no sentido metafórico. Mesmo sobrevivendo ao procedimento, essas mulheres ficarão com sequelas físicas e psicológicas.

\author{
Nos versos, \\ Sentir os frágeis ligamentos, \\ os nervos, \\ romperem as costuras \\ ante o dente rombo da tesoura. \\ Perceber a carne \\ ora cremosa, ora seca, \\ como uma folha seca, \\ se diluindo e se partindo. \\ (VERUNSCHK, 2003, p. 54).
}

As ações dão continuidade aos versos "Ver seu vermelho/em pálido esmaecer" (VERUNSCHK, 2003, p. 54), pelo movimento e pelos sentimentos do sujeito que faz a incisão. A partir da descrição desses movimentos e emoções, é possível perceber os efeitos trágicos do procedimento. Sentir que os ligamentos romperam as costuras, ou seja, os pontos estouraram, se desfaz diante do rombo provocado pela tesoura e provoca uma hemorragia que torna a carne seca, levando à morte.

Embora o poema tenha termos suaves em oposição aos atos grosseiros, caracterizando a perspectiva feminina da poeta, a expressão "rombo" destoa dessa sequência, pelo sentido manifesto no poema. Rombo diz respeito a uma abertura à força, com o emprego de violência. Portanto, não é um corte ou uma abertura feita cuidadosamente pela 
tesoura, como sugerem os primeiros versos. Trata-se de um rombo, algo feito contra a vontade da menina e por instrumentos de corte inapropriados. Assim, o que já é frágil, os lábios, "frágeis ligamentos" (VERUNSCHK, 2003, p. 54), por ser uma criança, não resiste à agressividade do ato.

A forma verbal "partindo" fınaliza uma série de ações postas de forma gradativa e que culminam na morte: romper, diluir e partir. Além de "partindo", a ideia da morte é acrescida também no verso pela expressão "como uma folha seca", que reforça a falta de vida do objeto. Também remete ao deserto, ao estéril, se pensarmos que a maioria das mulheres que sobrevive fica estéril. Nos últimos versos, o eu lírico retoma a tradição e o valor da infibulação como prática cultural ou ritual necessário: "E antes do fim,/colar tudo num álbum amarelo e vinho/e ir dormir em paz" (VERUNSCHK, 2003, p. 54). Não importam a gravidade e as consequências da incisão; não importa a morte da menina; o que importa é cumprir com a tradição e não se preocupar, pois a passagem ritualística precisava ser feita. Por isso, dorme-se em paz, como se isso fosse possível, reforçando mais uma vez a ironia presente no poema.

Os acontecimentos são postos de forma gradativa, iniciando com a identificação dos lábios finos, portanto de quem passa pelo procedimento, recuperando-se as ações do início ao fim pelo sujeito que faz o procedimento. Marcar, cortar e costurar, para depois romper, diluir e partir. Enquanto tudo isso acontece, o eu lírico também sente, mas tem que "colar" tudo no álbum para respeitar a tradição. O poema registra o estado do sujeito que faz a circuncisão e garante a representação dos seus movimentos e emoções e não a da poeta. Temos, então, a conversão da infibulação em objeto de poesia. Não há a expressão do estado emocional do poeta, mas sim do objeto representado. 0 direcionamento que a poeta dá ao sujeito que faz a infibulação demonstra esse distanciamento. É o outro que é observado por uma espécie de câmera durante o ritual que consegue captar suas ações e emoções. Se há intimidade, ela não é da poeta e sim do próprio objeto. A escolha da voz em $3^{a}$ pessoa também garante o seu distanciamento.

A voz poética parece recuperar a percepção de quem faz o procedimento para descrever também sua condição, uma condição que pode ser tanto de alguém que se importa apenas com a tradição como também de alguém encurralado na sociedade, sem direito a opinar. Essa ideia dá margem para a discussão das possibilidades de leituras que o poema permite. Ao falar da infibulação como ritual praticado em alguns países, o poema fala da mutilação genital feminina em nome de uma prática cultural que acredita que o ritual é necessário para o casamento da mulher, sendo uma condição prévia para tanto. Caso contrário, a mulher pode ser banida da sociedade. Essa condição, de certa forma, vai de encontro à privação de direitos das mulheres no tocante à desigualdade dos gêneros. A mutilação como garantia de relações sexuais apenas após o casamento acentua a condição da mulher nesse contexto. A ideia que a voz poética parece recuperar é a percepção do objeto, do outro, para descrever também sua condição, passando pela 
condição do outro ser mulher. Se preserva uma tradição, ela já passou por tal ritual e sabe das consequências tanto do ritual como também de não se submeter a ele.

Podemos pensar ainda em uma leitura além da condição cultural em que a infibulação como ritual acontece e ver a mutilação genital feminina presente em diversos contextos, inclusive no Brasil. Nesse sentido, o poema vai além e revela a condição não só do sujeito do poema, mas também da própria poeta na sua condição de mulher, estando presente como a consciência que poetiza. Talvez aqui a poeta consiga aquilo que Collot (2013) propôs: produzir seu canto mais particular, ocupando-se muito menos dele do que de outra coisa. Ao fazer isso, a poeta consegue se encontrar.

A percepção que pretendemos mostrar é que diariamente mulheres são mutiladas das mais diversas formas. O estupro, por exemplo, é um tipo de agressão sexual que se constitui também como mutilação. O discurso poético em torno da infibulação permite pensarmos nos muitos casos de crianças que são abusadas por pais, padrastos ou parentes próximos e por medo e ameaças à mãe, mesmo sabendo, acaba não denunciando, dando assim continuidade a uma tradição que reforça as diferenças entre gêneros. Também, com um desfecho trágico, milhares de mulheres são assassinadas como nos casos de feminicídio - após serem brutalmente violentadas. Nesse sentido, mais uma vez a voz poética recupera a percepção do objeto como "o outro" e revela sua condição, uma condição de silenciamento, apagamento e morte que a voz poética deseja externar e, por consequência, denunciar.

Há no poema "Infibulação" uma riqueza de imagens e ações que abre caminhos para possibilidades diversas de leituras, por exemplo, a partir de expressões como "mãos firmes", "ser terno", "linha de contorno", que dão ideia da objetividade e a sensibilidade da voz poética de Verunschk. Nesse sentido, a infibulação descrita pode evocar também as imagens e as ações do processo de criação poética. O poema apresenta a construção metafórica do fazer poético, expressando uma espécie de "Profissão de Fé" que reúne as características perceptíveis na poética de Verunschk. Os movimentos do ritual de mutilação da genital feminina configuram imagens que revelam também o ato de escrita.

Os movimentos realizados na infibulação, no ato de escrita do poema, dão o tom narrativo do poema, partindo da apresentação do objeto recortado ao término da execução do procedimento. Dessa forma, o fazer poético é um processo que passa pelas transformações captadas no poema. Essa performance é configurada na tessitura formal do mesmo. Os versos são livres e organizados em uma única estrofe, o que permite uma sequência favorável das ações que formam o ato. Apesar de o poema ser em única estrofe, a configuração dos períodos permite a construção das imagens e percepções constituintes dos vários movimentos presentes no ato. A pontuação é de extrema importância na construção rítmica, de maneira que, a cada fim de período, impõe-se uma nova imagem para reflexão. As pausas permitem que cada cena, cada movimento seja contemplado pelo leitor na reiteração dos sentidos. 
Cada período encerra um ato constituído de precisas observações e instruções que devem ser seguidas na construção poética. Os primeiros versos "recortados cuidadosamente à tesoura,/sem fugir da linha do contorno,/sem preencher falha alguma/com lápis ou batom" (VERUNSCHK, 2003, p. 54), do primeiro período, formam a imagem do processo de infibulação, de construção do poema, configurada na perspectiva do eu lírico. 0 segundo período, que destoa do primeiro na extensão, "Ter cuidado, mão firme", dá continuidade ao processo de escrita, apresentando características necessárias à ação do período anterior. A brevidade do período sugere o perigo que uma ação descuidada pode provocar. Por isso, é preciso objetividade, sem espaço para digressões que podem comprometer o sentido do poema.

O erro é fatal tanto à mutilação genital feminina como para o processo de criação poética. A mão firme necessária na seleção de palavras remete ao poema "Catar feijão" (1999), de João Cabral de Melo Neto. A mão firme é que permite o jogar fora dos feijões que boiarem e permitir que apenas os "grãos pesados" permaneçam. Esse cuidado impede a poesia de ser flutuante e intimista. A brevidade do período denota o aspecto enxuto que o poema deve ter.

A ação desse período encerra a postura da ação do período anterior, expresso nos versos "recortados cuidadosamente à tesoura,/sem fugir da linha do contorno,/sem preencher falha alguma/com lápis ou batom" (VERUNSCHK, 2003, p. 54). O aspecto enxuto do poema é demarcado pelo recorte cuidadoso à tesoura. O objeto tesoura destoa dos objetos utilizados, em muitas ocasiões, para fazer a mutilação genital feminina. O seu uso no poema garante a precisão do procedimento, pois deve seguir rigorosamente o contorno, para que falha alguma seja preenchida por lápis ou batom. Não há espaços para serem preenchidos pela subjetividade, pela imaginação. O poema é apoiado em palavras e construções sólidas, graves, duras, como os "grãos pesados dos feijões".

O poema, nessa filiação, é a transfiguração de um objeto. Essa performance deve ser feita de maneira que a imagem do objeto seja apreendida de forma precisa, sem espaços para percepções interiores. Por isso, seguir o contorno com a tesoura. Essa visão remete ao próprio movimento que caracteriza a saída do eu lírico para fora do espaço da subjetividade. O contorno preciso parece marcar os espaços: "interior" e "exterior", subjetividade e objetividade. Dessa forma, a intimidade revelada é a do objeto, da exterioridade percorrida pela voz lírica, presente na poesia de Verunschk. Configura-se a metáfora da descentralização do sujeito.

A escolha do objeto do poema em análise de Micheliny Verunschk demonstra o aspecto indigesto das palavras pesadas constituintes do processo de criação. A infibulação como ato cruel e desumano é o grão imastigável no poema. Concebe-se a poesia dura, capaz de quebrar os dentes, a poesia cortante extraída pela poeta na transformação do grotesco em objeto de poesia. Essa transformação deve ser feita de acordo com a percepção 
vista nos versos "Ser terno para que não sangre em demasia/e cantar quase ninando" (VERUNSCHK, 2003, p. 54). O poeta precisa ser claro, enxuto, mas também precisa ser sensível, ser "terno". Esse aspecto permite que a linguagem construída na formação das imagens do poema configure o lirismo e seus efeitos de sentido. A compreensão dessa performance permite ver, no próprio poema em análise, o contorno preciso da objetividade, a firmeza das palavras cortantes, o lirismo exterior ao sujeito, mas sem deixar de lado a sensibilidade poética. A perspectiva feminina sutil e ironicamente crítica da poeta, ao falar sobre um tema tocante na sua própria condição, revela uma necessidade de rever, de pensar sobre o tema, com um olhar sensível e objetivo. A sutileza que configura a linguagem do poema demonstra a ironia da poeta sobre a realização de um procedimento desumano, que agride a essência e a integridade da mulher.

Nos últimos versos, o eu lírico parece revelar a condição da própria poesia, da arte que luta para sobreviver, para resistir aos espaços duros, desérticos que se encontra. Por isso, é papel do poeta lutar para garantir sua sobrevivência. "E antes do fim,/colar tudo num álbum amarelo e vinho/e ir dormir em paz" (VERUNSCHK, 2003, p. 54). O processo de renovação da poesia, seu aspecto atemporal e universal, permite sua posterioridade. O "álbum amarelo e vinho" é a configuração da sua imortalidade, garantido a sua (re) existência no tempo. A poesia continuará viva e essa completude está também no leitor.

O fazer poético expresso ao longo do poema, de maneira bastante expressiva, revela também uma concepção de poesia extraída dos espaços da negatividade, próprios da poeta. A infibulação acaba sendo o sinônimo de infertilidade e infelicidade para as mulheres. É nesse espaço estéril, de frágeis ligamentos, como folha seca, que a poeta extrai a sua poesia. Espaço de silêncio, de abandono que caracteriza o deserto, tão fortemente demarcado na sua obra, é a fonte que sua voz poética parece sustentar. Nesses espaços nebulosos, marcados pela negatividade, nesse espaço estéril, a poesia ainda sobrevive.

A percepção do objeto revelada no poema reforça a ideia posta por Collot (2013), de que o sujeito sai de si e vai ao encontro do outro, do mundo. Assim temos uma configuração poética que se propôs a ir de encontro com o mundo, revelando o seu próprio desconcerto. E o outro, ao revelar sua condição, permite que o sujeito se revele também no encontro consigo, em um processo de regeneração. Essa percepção é vista tanto na poetização do processo de mutilação feminina, numa relação contextual, como na metáfora do processo de escrita da poesia.

Identificando-se com as coisas, o sujeito não procura consolidar sua identidade em torno de algum fetiche ou totem; abre-se para sua íntima alteridade, para suas virtualidades contraditórias: "Eu insisto em dizer, quanto a mim, que eu sou bem outra coisa, e, por exemplo, que além de todas as qualidades que eu possuo em 
comum com o rato, o leão e a rede, eu aspiro às do diamante e, aliás, eu me solidarizo, inteiramente, tão bem com o mar, quanto com o penhasco que ele ataca e com o seixo que, em consequência disso, é criado. Ponge escreve alhures: "A variedade das coisas é na realidade o que me constrói.". A poesia "objetiva" tem por principal objetivo a regeneração do sujeito e a renovação do lirismo. (COLLOT, 2013, p. 235).

Tudo isso colabora, no poema de Verunschk, para a construção da alteridade do eu que escreve. Afastando de si, ele se descobre. O eu surge do lado de fora, a interioridade é construída e revelada, na relação entre sujeito e objeto, movimentos externos e internos. O sujeito é modificado, é transformado pela consciência e pela descoberta feita a respeito do objeto. A construção do sujeito, dessa forma, surge a partir da captação do sujeito a um determinado objeto. Tal construção está relacionada ao fenômeno do conhecimento, que se estabelece na relação sujeito e objeto. Sem esses dois elementos, não acontece o ato de conhecer, que é, de acordo com Correia (2009, p. 140), realizado em três movimentos ou tempos: "Primeiro o sujeito sai de si, segundo: o sujeito está fora de si, e terceiro, regressa finalmente a si". Não é apenas o sair de si que consolida o conhecimento. É necessário que o sujeito apreenda o objeto, para que ocorra a transformação desse sujeito, e assim consolidar o conhecimento, a "regeneração" do sujeito, conforme Collot (2013). Essa transformação ressalta o movimento feito pela voz poética no poema "Infibulação". É possível perceber que o sujeito realizou os três movimentos; saiu de si, ficou fora de si e finalmente regressou a si. $\mathrm{O}$ ato de apreensão do objeto demonstra como ele recupera a sua própria voz, a partir de uma realidade, portanto de fatos, costumes, ideologias, existentes na experiência externa. É na condição do outro que ele se recupera.

Nesse ponto, a intimidade que é revelada e os movimentos registrados na poética de Verunschk são externos. Não se trata da poeta, mas do objeto que ela transformou em matéria de poesia. O objeto transformado pela poeta permitiu que ela, na apreensão do mesmo, revelasse também sua condição, manifesta na questão em volta da mulher, e seu processo de emancipação, e também sua condição de "poeta" ao integrar uma tradição poética que é caracterizada no próprio poema. Sua identidade como poeta e como mulher é expressa sem "desafogo desabrido".

João Alexandre Barbosa, no prefácio à Geografia íntima, afirma que a intimidade colocada no título da obra é a intimidade do objeto e não do sujeito:

Eis, portanto, um interessante e aparente paradoxo: uma poesia da intimidade, como esta sem dúvida é, não é necessariamente uma poesia intimista ou de intimidades. [...] uma poesia íntima, mas do deserto, e não do ou da poeta como subjetividade que venha se escancarar diante do leitor por uma linguagem de desafogo desabrido. (BARBOSA, 2003, p. 14). 
Nesse sentido, compreendemos que o sujeito lírico na poética de Verunschk se descentraliza à procura de outros espaços, de outras intimidades. Sai da interioridade pura e vai de encontro com o outro em um movimento que é sempre do outro e não do sujeito em si. É, necessariamente, estabelecer representações que incorporam na sua estrutura e conteúdo, espaços coletivos ou individuais, que captem o movimento do homem na história. Uma perspectiva que englobe, simultaneamente ou não, o passado e o presente, de maneira que revele o sujeito e suas relações possíveis. Assim, o poeta, em sua performance, consegue interpretar intimidades que são indicadoras e reveladoras da condição de cada indivíduo representado. O enfoque é direcionado ao mundo, aos objetos, de maneira que, nesse movimento, o eu que fala pode ser introjetado, pelo encontro permissível do sujeito com o mundo, ao revelar condições pares. A descentralização presente no poema é configurada tanto pela leitura poética de um ritual, infibulação, quanto pela construção da metáfora do processo de construção do poema.

\section{REFERÊNCIAS}

BERARDINELLI, A. Da poesia à prosa. Tradução Maurício Santana Dias. São Paulo: Cosaic Nayf, 2007.

BOSI, A. Sobre alguns modos de ler poesia: memórias e reflexões. In: BOSI, A. Leitura de poesia. São Paulo: Ática, 1996.

COLLOT, M. O sujeito lírico fora de si. Tradução Zênia de Faria e Patrícia Souza Silva Cesaro. Signótica, UFG, v. 25, n. 1, p. 221-241, jan./jun. 2013.

COMBE, D. A referência desdobrada. O sujeito lírico entre a ficção e a autobiografia. Tradução Iside Mesquita e Vagner Camilo. Revista USP, São Paulo, n. 84, p. 112-128, dez./ fev. 2009-2010.

CORREIA, F. S.; MAGALHÃES, J. B. Introdução à Filosofia $17^{\circ}$ Ano. Rio de Janeiro: Edições Contraponto, 2009.

FRIEDRICH, H. Estrutura da lírica moderna. Tradução Marise M. Curioni e Dora F. da Silva. 2. ed. São Paulo: Duas Cidades, 1991.

HAMBUGER, M. A verdade da poesia: tensões na poesia modernista desde Baudelaire. Tradução Alípio Correia de Franca Neto. São Paulo: Cosac \& Naify, 2008.

HEGEL, G. W. F. A poesia lírica. In: HEGEL, G. W. F. Curso de estética. São Paulo: Martins Fontes, 1997. p. 510-555. 
NETO, J. C. de M. Obra Completa. Rio de Janeiro: Nova Aguilar, 1999.

ORTEGA Y GASSET, J. A desumanização da arte. 5. ed. Tradução Ricardo Araújo. São Paulo: Cortez, 2005.

STAIGER, E. Conceitos fundamentais de poética. Tradução Celeste Aída Galeão. Rio de Janeiro: Tempo Brasileiro, 1969.

VERUNSCHK, M. Geografia íntima do deserto. São Paulo: Landy Editora, 2003. 